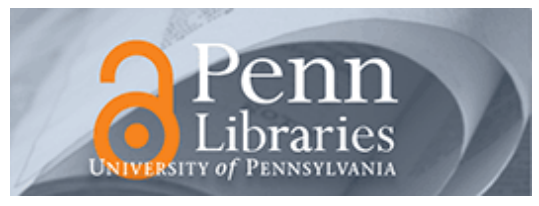

University of Pennsylvania

ScholarlyCommons

October 2006

\title{
Peer Support for African American Male College Achievement: Beyond Internalized Racism and the Burden of "Acting White"
}

Shaun R. Harper

University of Pennsylvania, sharper1@gse.upenn.edu

Follow this and additional works at: https://repository.upenn.edu/gse_pubs

\section{Recommended Citation}

Harper, S. R. (2006). Peer Support for African American Male College Achievement: Beyond Internalized

Racism and the Burden of "Acting White". Retrieved from https://repository.upenn.edu/gse_pubs/168

Reprinted from The Journal of Men's Studies, Volume 14, Issue 3, Fall 2006, pages 337-358.

This paper is posted at ScholarlyCommons. https://repository.upenn.edu/gse_pubs/168

For more information, please contact repository@pobox.upenn.edu. 


\title{
Peer Support for African American Male College Achievement: Beyond Internalized Racism and the Burden of "Acting White"
}

\begin{abstract}
Theorists posit that the social reinforcement of racially oppressive assumptions eventually works its way into the psyche of African Americans and negatively shapes the way they see themselves and others within their race. Some scholars have attempted to prove and others have subsequently disputed the idea that school achievement within African American peer groups is seen as "acting White." In this study, internalized racism and Fordham and Ogbu's (1986) Acting White Hypothesis were explored among highachieving African American male undergraduates at six predominantly White universities. Findings from individual interviews contradict the hypothesis and reveal ways through which peer support for leadership and achievement were negotiated within African American peer groups on the six campuses. There was no evidence of internalized racism in the domains of academic achievement and African American male leadership. Instead, the participants attributed much of their college success to the support offered by their same-race peers.
\end{abstract}

\section{Keywords}

academic achievement, African Americans, higher education, peer influence, race

\section{Comments}

Reprinted from The Journal of Men's Studies, Volume 14, Issue 3, Fall 2006, pages 337-358. 


\title{
Peer Support for African American Male College Achievement: Beyond Internalized Racism and the Burden of "Acting White"
}

\author{
Shaun R. Harper \\ The Pennsylvania State University
}

\begin{abstract}
Theorists posit that the social reinforcement of racially oppressive assumptions eventually works its way into the psyche of African Americans and negatively shapes the way they see themselves and others within their race. Some scholars have attempted to prove and others have subsequently disputed the idea that school achievement within African American peer groups is seen as "acting White." In this study, internalized racism and Fordham and Ogbu's (1986) Acting White Hypothesis were explored among high-achieving African American male undergraduates at six predominantly White universities. Findings from individual interviews contradict the hypothesis and reveal ways through which peer support for leadership and achievement were negotiated within African American peer groups on the six campuses. There was no evidence of internalized racism in the domains of academic achievement and African American male leadership. Instead, the participants attributed much of their college success to the support offered by their same-race peers.
\end{abstract}

Keywords: academic achievement, African Americans, higher education, peer influences, race

More than any other group of men in our society, Black males are perceived as lacking in intellectual skills. Stereotyped via racism and sexism as being more body than mind, Black males are far

Shaun R. Harper, Center for the Study of Higher Education, The Pennsylvania State University.

The author wishes to express his gratitude to all the participants in this study and to acknowledge their wish to use their "real" names and the names of their institutions in the article.

Correspondence for this article should be addressed to Shaun R. Harper, Center for the Study of Higher Education, The Pennsylvania State University, 400 Rackley Building, University Park, PA 16802. Electronic mail: sharper@psu.edu

The Journal of Men's Studies, Vol. 14, No. 3, Fall 2006, 337-358.

(C) 2006 by the Men's Studies Press, LLC. All rights reserved.

1060-8265.14.337 
more likely to be affirmed for appearing to be dumb ... well-educated Black men have learned to act as if they know nothing in a world where a smart Black man risks punishment. (hooks, 2004, p. 33)

In her book, We Real Cool: Black Men and Masculinity, author and activist bell hooks (2004) discusses the deleterious effects of mass media images, within-race disempowerment, and class-based education on African American male socialization. Accordingly, young African American men are groomed to devalue educational achievement, as due to societal messages that are internalized and reinforced by Black families and peers. She notes that in some Black households the boy who likes to read is suspected to be at risk for developing feminine or "sissy" characteristics - the same perceptions held among Black male peer groups in schools are often juxtaposed with low teacher expectations for Black male school success. Consequently, few receive the support needed to overcome longstanding educational inequities and societal disadvantages. While White teachers, school administrators, and educational structures that maintain White supremacy are largely responsible for African American male underachievement, equally troublesome is the internalization and validation of these messages within Black communities.

Internalized racism (or internalized oppression) occurs when socially stigmatized groups (e.g., Black males) accept and recycle negative messages regarding their aptitude, abilities, and societal place, which results in self-devaluation and the invalidation of others within the group (Essed, 1991; Jones, 2000; Lipsky, 1987; Pheterson, 1990; Pyke \& Dang, 2003). That is, the oppressed begin to believe in their own inferiority, both individually and collectively (Baker, 1983). In turn, members of the group consciously or unknowingly endorse the ideologies of the oppressor by communicating counterproductive and racist messages to other group members. Ultimately, within-group socialization toward negative and what is perceived as racially normative codes of conduct often ensues. Lipsky (1987) makes clear that this tendency is not a source of racism but instead an internalized reaction to externally imposed oppression.

Lipsky (1987) also partially attributes failed attempts at Black collectivism and liberation as well as the leadership decline within Black communities to internalized racism. Specifically, she asserts that internalized oppression compels African Americans to criticize, attack, or have unrealistic expectations of those who willingly step forward to assume leadership responsibilities. Thus, Lipsky maintains, the support needed for effective Black leadership is rarely extended, which causes burnout among African American leaders. Patricia Hill Collins (2004) contends that Black male elected officials, business leaders, executives, and academicians are thought to be "intellectual sissies" who align themselves too closely with White culture:

Staying in school and studying hard moves them closer to images of Bill Cosby selling Jello or Michael Jordan talking to Bugs Bunny or Tiger Woods refusing to claim Blackness at all. If the "academic sidekick" or "intellectual sissy" becomes seen by African American boys and young men as the price they have to 
pay for racial integration, it should not be surprising that increasing numbers of Black men reject this route to success. (p. 177)

As a result, few low-income and working-class African American males aspire to careers in leadership or pursue the educational credentials requisite for assuming such positions; those who do rarely receive support and validation from their samerace peers.

Internalized racism erodes individual enthusiasm, makes certain attitudes and behaviors normative, and undermines collaborative action for racial uplift (Jones, 2000). For example, instead of collectively striving to dispel faulty stereotypes regarding African Americans, many will endorse those misperceptions by encouraging Black male athleticism over intellectualism, as one example. Paulo Freire (1970) discussed the "self-deprecation" phenomenon, which he characterized as a sense of self-hatred and low self-esteem among the oppressed. "So often do [the oppressed] hear that they are good for nothing, know nothing, and are incapable of learning anything - that they are sick, lazy, and unproductive-that in the end they become convinced of their own unfitness" (p. 94). For African American males, nowhere is this oppression more commonplace than in schools, the context in which an achiever is supposedly accused by his same-race peers of "acting White."

The anti-college-going messages articulated in rapper Kanye West's (2004) debut album, The College Dropout, blatantly suggest postsecondary education is overrated and degree attainment is culturally worthless. Several skits on the album feature a fictitious African American male collegian who speaks in a voice that would be characterized by most as White. Marketed primarily to Black listeners, these lyrics were consumed by millions, which offers an example of the commercialization and mass production of internalized racism. Although college attendance is likened to Whiteness in West's album, most conceptual, theoretical, and empirical considerations of internalized racism within the context of schooling have focused on African American students in K-12 settings. Thus, little is known about peer attitudes and support tendencies among African American college students. Even less attention has been devoted to considering dynamics among African American male undergraduates, the population that is least retained among both sexes and all racial/ethnic groups in higher education (Harper, 2006a; NCES, 2005). The purpose of this study is to explore the role of peers in the postsecondary educational experiences of African American male high-achievers at predominantly White universities. The emphasis placed on peers in this article is important, as Astin (1993) contends, peers are most influential in the experiences of undergraduate students.

\section{Literature Review}

Few researchers have examined the experiences of academically talented African American college students in general (Fries-Britt, 1998, 2002, 2004; FriesBritt \& Turner, 2001, 2002; Griffin, 2006) and male high-achievers specifically (Bonner, 2001; Fries-Britt, 1997; Harper, 2004, 2005a, 2005b, 2006b). Therefore, the use of literature from the K-12 school studies was necessary to provide a context for this study. 


\section{African American Peers and Early Schooling Experiences}

Studies regarding the experiences of gifted and academically talented African American youth are fraught with descriptions of negative peer interactions. Reportedly, these students are forced to contend with complex social and emotional adjustment issues in school, including the development of healthy self-concepts and feelings of belongingness (Baldwin, 1991; Ford, 1996; Lindstrom \& Van Sant, 1986). Moreover, high-achievers often encounter difficulty integrating their social, racial, and academic identities (Cooley, Cornell, \& Lee, 1991; Ford \& Harris, 1997). The title of Kunjufu's (1988) book, To Be Popular or Smart: The Black Peer Group, captures the essence of this struggle. Ford (1996) suggests many academically talented African American students purposely underachieve in school and hide their intellectual competence in order to negotiate cultural entrée into Black peer groups. Fordham and Ogbu (1986) refer to this as "camouflaging," while Horvat and Lewis (2003) report that such acts are part of managing academic success. "When caught in this psychological and social-emotional tug-of-war, some Black students attempt to sabotage their achievement [by] procrastinating, failing to do assignments, and refusing to be in gifted education and advanced-level classes" (Grantham \& Ford, 2003, p. 22).

In their study of gender differences among African American students, Ford and Harris (1995) found that more than 40 percent of the participants in the sample were underachieving, a disproportionate number of whom were men. Furthermore, female students in the sample also had significantly higher grade point averages than their male counterparts. At least a portion of these achievement differences is explained by hegemonic conceptions of masculinity among African American boys and teens. According to James Earl Davis (2003), African American males tend to set the standards for popularity at school mostly through hip-hop culture and athleticism, and there is often little room for negotiation within peer groups. The African American male middle school students in Davis's (2001) study developed a strict masculine code of conduct in their school that was characterized by various socially constructed attitudinal and behavioral norms that were in conflict with academic achievement. Examples include pursuing romantic relationships (but not friendships) with female students and being perceived as "cool." Davis found that those who failed to adhere to the masculine code were victimized by their peers and "usually expelled from the confines and benefits of boy networks at the school" (p. 178).

While the focus of this article is on peers, it should be noted that the subtractive and invalidating ethos of predominantly White K-12 school environments often lead African American students to assume that academic achievement is incongruent with their cultural interests and values (Gay, 2000; Hollins \& Spencer, 1990; Irvine, 1990; Ladson-Billings, 1995), which in turn leads to the perpetuation of internalized racism. Grantham and Ford (2003) argue that too few efforts are employed to improve Black student achievement in school and educators need to focus on helping academically talented students develop healthy racial identities and affirming relationships with their same-race peers. 


\title{
The "Acting White" Hypothesis
}

Signithia Fordham and John Ogbu's (1986) study illuminates many of the aforementioned elements of internalized racism. Specifically, they contend that academically successful African American students must cope with the burden of being constantly accused of "acting White" by their peers:.

\begin{abstract}
Black students' academic efforts are hampered by both external factors and within-group factors ... schooling is perceived by Blacks, especially by Black adolescents, as learning to act White, or as trying to cross cultural boundaries. And, importantly, school learning is viewed as a subtractive process. In our view, then, the academic learning and performance problems of Black children arise not only from a limited opportunity structure and Black people's responses to it, but also from the way Black people attempt to cope with the "burden of 'acting White."' (p. 201)
\end{abstract}

Fordham and Ogbu purport that this burden plays itself out in predominantly Black and racially integrated school settings. Furthermore, they say social ostracism, exclusion from Black activities inside and outside of school, labeling, and even physical assault are among the challenges with which academic achievers must contend. Others have referred to this phenomenon as "oppositional peer culture" (Ainsworth-Darnell \& Downey, 1998; Ferguson, 2001). Fordham (1988) adds that some high-achieving African American students embrace "racelessness"-meaning they distance themselves from Black culture as a response to the lack of same-race peer support they receive at school.

According to Ogbu and Simons (1998), African American students are usually supportive of their same-race peers when they earn good grades, but it is the embracing of perceivably White attitudes and behaviors used to earn those grades that are deemed problematic. In addition to the ramifications noted earlier, Ogbu (2004) asserts that the burden of "acting White" includes accusations of being an "Uncle Tom" or "sellout," perceived disloyalty to the Black community, personal embarrassment and public humiliation, and a loss of Black friends. He suggests that mentors can serve as mediators against peer pressure and self-doubt but indicates that mentorship is typically not extended to Black achievers. Ogbu also posits that academically talented students feel compelled to conduct, either formally or informally, a "social cost-benefit analysis" of school success, and they then act accordingly.

Fordham and Ogbu's hypothesis has been the center of contention in subsequent studies of Black student achievement (see Ainsworth-Darnell \& Downey, 1998; Cook \& Ludwig, 1998; Ferguson, 2001; Spencer, Noll, Stolzfus, \& Harpalani, 2001). These researchers have consistently found that African American students do not value education or school achievement any less than do their White peers from similar socioeconomic or familial backgrounds, and that many high-achievers have positive self-esteem, high goal orientations, and strong Black identities. In their study of Black female students in urban high schools, Horvat and Lewis (2003) found that Black peer groups affirmed, embraced, and celebrated the participants' 
academic achievements. It should be noted that the women in the Horvat and Lewis study were also actively involved in a range of out-of-class activities at their high schools, which their peers reportedly sanctioned and supported.

Ferguson (2001) contends that achievement is more negotiable among African American students than Fordham and Ogbu's work suggests. He argues that those who are interested in school success must invest effort into academic endeavors while signifying an authentic sense of racial solidarity with their African American peers. Ferguson rejects the "acting White" hypothesis and offers an alternative perspective on oppositional culture that he characterizes as uniquely African American:

\begin{abstract}
Among its essential features is the drive to maintain a shared sense of African American identity that is distinct from (that is, in opposition to) the Other ... the Other is not White people, especially as individuals. Instead, the Other is the cultural system of White superiority within which negative racial stigma is kept alive and out of which insinuations of Black inferiority and marginality emanate. Black racial solidarity serves as a mechanism of mutual validation and a shield ... any apparent attempt by a Black person to escape the stigma of race by joining the Other-by speaking and behaving in ways that appear to seek an exemption from the stigma while leaving it unchallenged - may meet the accusation of acting White. (pp. 377-378)
\end{abstract}

\title{
Peer Influences on African American College Achievement
}

Limited insight has been offered into the role of peers in African American college achievement. Fries-Britt (1998) found that many academically talented students entered college with few or no relationships with other high-achieving African American students. These students came from primary and secondary schools where most of their time was spent in gifted programs with few of their same-race peers. As with their early schooling experiences, many of the participants were primarily enrolled in classes with White students in the honors college at their university. Consequently, they had few opportunities to interact with other African Americans and relied heavily upon a special program for minority achievers to meet other students from their race. Because of limited interactions with their same-race peers, Fries-Britt (2002) posits that high-achievers become aware that they belong to an underrepresented group and accustomed to not expecting other African Americans to do well.

Fries-Britt and Turner (2002) assert that some African American students purposely assimilate into White culture, which does not necessarily mean they know less about Black culture or have weaker racial identities. Instead, they "have learned to become bicultural, developing a repertoire of expressions and behaviors from both the White and Black community and switching between them as appropriate" (p. 320). The participants in Fries-Britt's (1998) study reflected on the uneasy exchanges they had with other African American students who were not in the program for academically talented collegians. On the one hand, they valued the affiliation with a program that facilitated interactions with other academically talented 
African Americans, but on the other, the participants longed for opportunities to be connected to the larger African American community on campus. Some students admitted to camouflaging their academic talents and concealing their connection to the program in order to fit in with other African American students at their university. Fries-Britt (1997) specifically addresses the needs of and issues faced by highachieving African American undergraduate men. She notes that pressure to fit in with and earn the respect of their male peers is a considerable source of stress for male high-achievers. Athletic ability, instead of academic talent, is one characteristic that garnered peer recognition within Black male peer groups.

Though not based on high-achievers, Davis's 1994 and 1999 comparative studies of African American undergraduate men at historically Black colleges and universities (HBCUs) and predominantly White institutions (PWIs) show that students at both institutional types report comparable levels of peer support. Bonner (2001) examined two high-achieving African American male students' perceptions of the impact of peer relationships on their academic success in college; one participant attended an HBCU, and the other was enrolled at a PWI. Both participants acknowledged the academic and social support they received from peers that led to increased confidence in their abilities. Interestingly, the HBCU student believed his campus environment nurtured and encouraged high achievement; thus, he comfortably displayed confidence in his academic abilities. The PWI student, on the other hand, "maintained that he did not wear his academic talent on his sleeve, but preferred to be more subtle and unassuming regarding his scholastic achievements" (p. 11). Bonner concluded that the predominantly White campus environment contributed to this student's discomfort with flaunting his giftedness. Neither Davis nor Bonner disclose the outlets through which peer support was derived or the strategies the African American male participants in their studies undertook to leverage same-race peer support.

Limited empirical exploration of the "acting White" hypothesis within the context of higher education, as well as the inconclusiveness and lack of specificity in the existing published research regarding same-race peer support for African American male college achievement, call into question the following: (1) What roles do African American peers play in the experiences of high-achieving African American male undergraduates at PWIs, (2) through what outlets is peer support derived, (3) how is same-race peer support garnered and negotiated among African American male achievers at predominantly White universities, and (4) what support is there for the "acting White" hypothesis and internalized racism among African American male collegians? These questions were investigated in this study.

\section{Method}

This article is based on a larger qualitative data set regarding the experiences of high-achieving African American undergraduate men. Data used here were extracted from a more comprehensive project. The phenomenological study sought to understand what it is like to be a high-achieving African American male college student at a large, predominantly White university and included questions regarding relationships with and support derived from others. The phenomenology tradition in qualitative 
research focuses on understanding and describing the "lived experiences" of the participants involved in the study (Denzin \& Lincoln, 2000). A phenomenological account gets inside the common experience of a group of people and describes what the participants have experienced, how they have experienced it, and the meanings they make of their shared experience (Moustakas, 1994). Polkinghorne (1989) suggests that the researcher and readers of a phenomenological research study should be able to say, "I understand better what it is like for someone to experience that" (p. 46). This type of qualitative study usually provides full, detailed descriptions of the phenomenon under study (Miles \& Huberman, 1994). The aim of the present study was to capture, in the high-achievers' words, perceptions of same-race peer support for college achievement and strategies through which peer relationships were negotiated.

\section{Sites}

This study was conducted at six large, public research universities in the Midwest: the University of Illinois, Indiana University, the University of Michigan, Michigan State University, The Ohio State University, and Purdue University. These six institutions are similar in terms of size, age, reputation, and selectivity. Collectively enrolling more than 189,000 undergraduates, these six institutions were all classified as Doctoral/Research Universities-Extensive by the Carnegie Foundation for the Advancement of Teaching (2000). On average, 6.3 percent of the students at the institutions were African American during the time at which data were collected, with African American undergraduate enrollments ranging from 3.1 percent to 8.8 percent. The mean six-year graduation rate for African American male undergraduates at these institutions was 50.7 percent, compared to 74.2 percent for White males and 58.8 percent for African American females. Consistent with national trends (Harper, 2006a), African American men had the lowest graduation rates among both sexes and all racial/ethnic groups across the six universities. At the time of data collection, 33.8 percent of the African American students at these universities were male.

\section{Sample}

Key administrators on the six campuses (i.e., deans, vice presidents, and directors of campus programs) were asked to identify high-achieving African American male student leaders who had earned cumulative grade point averages above 3.0 on a 4.0 scale, established lengthy records of leadership and involvement in multiple campus organizations, earned the admiration of their peers (as determined by peer elections to campus leadership positions), developed meaningful relationships with faculty and high-ranking campus administrators, participated in enriching educational experiences (e.g., study abroad programs, internships, learning communities, and summer research programs), and earned numerous awards and honors for their college achievements. Using these criteria, 32 African American undergraduate men at the six universities were identified and selected for participation in this study.

The sample included four sophomores, 12 juniors, and 16 seniors, representing a wide variety of academic majors. The mean GPA for the sample was 3.32. All of 
the participants were between the ages of 18 and 22 and single with no dependents. Twelve participants grew up in single-parent homes, and the remaining 20 were from homes with two parents. Regarding the educational levels of their parents, the participants reported the following: both parents attended college $(n=9)$; one parent attended college $(n=10)$; and neither parent attended college $(n=13)$. Collectively, the 32 participants had been awarded more than $\$ 489,000$ in merit-based scholarships, awards, and prizes for their college achievements. The participants expressed high educational and career aspirations, with 72 percent indicating the intent to someday earn a doctoral degree. The remaining 28 percent planned to pursue master's degrees, mostly MBAs from top business schools.

None of the participants in this study were college student-athletes. Nominators reported that these 32 high-achievers were the only African American male undergraduates on the six campuses who satisfied the previously noted criteria established for participation in this study.

\section{Data Collection Procedures}

Each of the 32 African American men was asked to participate in a two-to-three hour face-to-face interview and at least two follow-up interviews via telephone. I visited each campus at least once to conduct the first round of individual interviews; four campuses were visited twice. A semi-structured interview technique was used in the face-to-face interview sessions, which simultaneously permitted data collection and authentic participant reflection (Holstein \& Gubrium, 1995). Although standard questions and interview protocol were used in the interviews, discussions often became conversational, thus allowing the participants to reflect on the experiences they deemed most significant. Full transcripts from all sessions were sent to each participant for confirmation within eight weeks following his interviews.

\section{Data Analysis}

Step-by-step techniques prescribed by Moustakas (1994) were used to analyze the data collected from interviews with the participants. I first bracketed my initial impressions and assumptions as I read each line of the participants' transcripts. The margins of the transcripts were marked with reflective comments regarding my own suppositions and preliminary judgments about the data. After bracketing, the transcripts were sorted and key phases were linearly arranged under tentative headings using the NVivo ${ }^{\circledR}$ Qualitative Research Software Package. This process resulted in the identification of 36 invariant constituents (Moustakas, 1994), which were subthemes that consistently held true for at least 84.4 percent of the sample. The invariant constituents were helpful in understanding the participants' shared experiences and were later clustered into thematic categories.

Before the categories were solidified, a textural summary (what the highachiever experienced) and a structural summary (how he experienced the phenomenon of being an actively engaged student leader at a PWI) were written for each participant. Seven thematic categories were identified that captured the essence of the participants' shared experiences, two of which related directly to the role of 
peers in the high-achievers' experiences and success on predominantly White university campuses. Only findings from those two themes are reported in this article.

\section{Trustworthiness and Quality Assurance}

Several steps were taken to ensure quality and trustworthiness in this study. Lincoln and Guba (1986) offered four measures for evaluating methodological rigor and accuracy in qualitative research: credibility, transferability, dependability, and confirmability. These four measures "replace the usual positivist criteria of internal and external validity, reliability, and objectivity" used to ensure quality in quantitative studies (Denzin \& Lincoln, 2000, p. 21). Credibility was addressed through member checks, follow-up interviews via telephone, and referential adequacy (the storage and accessibility of cassette tapes from the interviews, full transcripts and confidential documents, etc.). An informant team consisting of at least two participants from each institution was established for member checks. This team, representing more than 25 percent of the sample, read and provided feedback on my written interpretations of their collective experiences.

To ensure credibility, feedback was solicited from six peer debriefers who are experienced qualitative researchers and are familiar with African American men's issues. Debriefers were given raw transcripts as well as the individual textural and structural descriptions I wrote for the study participants. Debriefers and I engaged in a series of ongoing discussions regarding the tentative meanings I made of the highachievers' experiences throughout the data analysis phase of the study. Transferability is ensured by the earlier description of sites from which data were collected. Findings from this study will likely transfer agreeably to large predominantly White public research universities. Last, to ensure dependability and confirmability, audits were conducted by members of the aforementioned peer debriefing team, a diverse team of four senior faculty colleagues, and one additional qualitative research methodologist.

\section{Limitations}

Despite efforts to ensure trustworthiness, two methodological and analytical shortcomings are readily apparent. The most glaring limitation of this study is the reliance on self-reported data of peer perceptions. Interviews were only conducted with the 32 high-achieving African American undergraduate men, not their peers. Although the participants believed their same-race peers held certain views of them, other African American students on the six campuses may have reported something different. A second major shortcoming pertains to the limited transferability of the findings from this study. High-achieving African American male students at singlesex institutions, HBCUs, small liberal arts colleges, and other institutional types might report peer interactions and experiences that differ from those of the 32 participants who attended the six large PWIs in the present study. 


\section{Findings}

From the interviews with the 32 high-achievers emerged three categories of findings regarding their experiences with other African American college students. Reported below are descriptions of peer support, the outlets through which this support was accessed, and the ways in which the high-achievers negotiated and leveraged support among their same-race peers on the six university campuses.

\section{Self-Reports of Peer Support}

Peers played a significant role in the high-achievers' collegiate successes. Reportedly, male and female students alike extended tremendous support to the African American men in the sample. No participant reported social ostracism or feelings of alienation from other African American students. Instead, they all described how peer support significantly enhanced the quality of their experiences as high-achievers in predominantly White learning environments. "There is no way I would have been nearly as successful at Ohio State were it not for the support of other African American students here. They have applauded everything I have done so far," Cullen noted. Other participants indicated that they would have accomplished less without the support of other African Americans. When asked to whom they would attribute their college achievements, the high-achievers consistently replied: (1) God, (2) themselves, (3) their parents, and (4) their peers-almost always in that order.

Although the participants had fostered meaningful relationships with students outside the African American race, they repeatedly reported that their African American peers had been most encouraging and validating. "The Black community is happy to see someone doing something positive, so that's why they've been so supportive," one high-achiever claimed. Several participants attributed this provision of peer support to the underrepresentation of African American male students on their campuses (recall that they comprised only one-third of the African American undergraduates at the six universities). Furthermore, the shortage of African American male student leaders on campus seemingly worked to their advantage in terms of garnering peer recognition for their leadership efforts and academic achievement. Bryant noted:

They know how it is to be the only African American student in all of your classes and they know that most Black organizations on campus are led by African American women, not the brothas'. So, when they see a brotha' who is involved and stepping up to be a leader in class or outside of the classroom, they are especially proud and supportive.

Jibreel added that because African American male achievers and leaders were "few and far between," he was easily noticed by his same-race peers, and they were generally inclined to encourage his success. 
It is especially important to acknowledge the participants' perceptions of support from other African American male students on campus. "I think 99.9 percent of the African American men have accepted me, even though I wasn't necessarily looking for their acceptance. They respect me; they don't look at me as some type of sellout," Michael shared. Most of the high-achievers' same-race male peers were considerably disengaged, did not pursue involvement opportunities or leadership positions on campus, struggled academically in their classes, and devoted their out-of-class time to playing video games, pursuing romantic endeavors with women, and participating in sports and fitness activities. Despite differences in the expenditure of their time, the high-achievers maintained that their disengaged male peers supported them, recognized their efforts and contributions, and never questioned their masculinities. Alric's comments illuminate this shared perspective: "Even though they aren't leaders and could probably care less about being involved themselves, they always support and uplift me nonetheless." No participant reported that he had ever been accused of "acting White" because he chose to do well in his classes or devote his out-of-class time to educationally purposeful activities. In fact, it appears that the exact opposite occurred - their African American male and female peers applauded their achievements and helped the participants make the most of their college experiences.

\section{Outlets for Same-Race Peer Support}

In addition to describing the affirmation extended by their African American peers, the participants also discussed the processes and venues through which they accessed peer support. First, several students noted that peers aided in their successful adjustment to college. Arnold, a senior at Indiana University, offered the following reflection of his experience in the Pharaoh's Club, a support group for African American males (typically first-year students) at IU:

I felt really connected to the guys in that group, so I really connected with the university from the start. Since then, I was like, "Okay, this was a good experience." I mean, I didn't feel alone on campus because I had that group of guys that I was always going back to for support. We were all taking the same classes and experiencing the same things as freshmen. So I learned that organizations and friends in those organizations could really help in that transition from high school to college. Those friends in the Pharaoh's Club really helped me.

Edwin expressed similar views regarding the relationship between involvement in student organizations and peer support:

The University of Michigan is a huge place. You're talking about 35,000 people. If you're not involved, I don't understand how you have friends. Joining these clubs and getting in leadership roles is how I have met a lot of my Black friends and supporters. 
Without exception, each participant mentioned clubs and activities, especially predominantly Black student organizations, as the venues through which he initially accessed same-race peer support for his college achievements and leadership.

As they became increasingly engaged in student organizations, the high-achievers noted that peer support for their pursuit of leadership also escalated. Because their involvement and leadership were overwhelmingly (but not exclusively) situated in predominantly Black student organizations, the participants relied heavily on African American students to support their agendas and quests for advancement. Paul, a student at the University of Illinois, provided the following reflection:

In becoming a student leader, other students motivated me with their words and their affirmations of the things I was doing. Just saying, "Paul, you know, you're doing such a great job; I really hope that you continue to be involved in this, and we have a meeting for this on Monday ... I hope you'll come and run for this position." People just motivated me and they thought more positively of me than I was thinking of myself at times.

Paul served as president of the National Association for the Advancement of Colored People (NAACP) chapter at the University of Illinois; president of Iota Phi Theta (a predominantly Black fraternity); coordinator and treasurer of the African American Advisory Board Peer Recruitment Program; treasurer of the Black Student Union; and a member of the Association of Black Cultural Centers national conference committee. This level of participation in elected and appointed positions confirms the high regard in which his African American peers held his leadership. Otherwise, they would not have elected him to all these positions in predominantly Black student organizations, Paul believed.

The high-achievers also suggested their African American peers supported them simply because they were African American. This was critical for those who were involved in mainstream and predominantly White student organizations. "They don't really know what the organization does, but because they feel this camaraderie with another African American student who's running for a particular leadership position, they're going to vote for that student because he or she is Black." Keely Stewart suspected he was elected Student Representative to the Board of Trustees at the University of Illinois in part because of the support he received from African American students who had no clue who he was but knew he was African American. Similarly, Christopher, who served as vice president of the student government on his campus, said many African American students did not know him personally, "but they at least knew I was Black, some were aware that I'm in Kappa Alpha Psi [a predominantly Black fraternity], and maybe a few had caught a glimpse of my leadership in previous roles." Therefore, they cast their votes in Christopher's favor during the student government election.

Forty-one percent of the participants held membership in one of the five national historically Black fraternities on their campuses. It should be made clear that fraternity affiliation is not requisite for African American male achievement or the acquisition of peer support at PWIs, as more than half of the participants in this study were 
unaffiliated. However, the 13 fraternity men in the sample acknowledged the organizations as an additional outlet for peer support and affirmation. They spoke at length about the value of having a close-knit group of African American male peers for whom achievement was important. Ted, then president of the Alpha Phi Alpha fraternity chapter at Purdue, noted that fellow members consistently encouraged academic achievement and were proud when he and the others did well. Ted also described various achievement incentives and recognition initiatives within the fraternity. Brian added, "Kappa Alpha Psi's fundamental purpose is achievement. Everyone in the chapter works to uphold this principle, and we support each other and hold each other accountable." All the fraternity men recalled the support their fellow chapter members extended as they sought major campus leadership positions as well as when they faced academic hardships and reached academic milestones.

In addition to fraternity brothers, the high-achievers also described the positive relationships they had formed with other African American male student leaders on campus. Many intentionally chose to surround themselves with guys who were "going somewhere," doing positive things on campus, and staying clear of trouble. This was the case both in high school and in college. On every campus I visited, each participant knew and had relationships with the other high-achieving African American male students I was interviewing. "The ironic thing is that I probably know every single person on the list that you're interviewing here at Purdue. We all know each other because we all support each other," David commented. As one participant walked out of the room and another entered, it was obvious that they knew each other well. It was not uncommon for two participants to shake hands, engage in the characteristically masculine "half hug," or strike up a brief conversation between the interviews.

The participants also had no problem admitting that some of the other participants in this study helped pave the way for them. For instance, Indiana University student Marshawn noted:

Christopher Smith [another participant] was an orientation leader the summer before I was an orientation leader; he was a Union Board Director the year before I became a Union Board Director; and he was in IUSA the year before I was in IUSA. Primarily, I have followed him.

Although they were members of different fraternities, Christopher served as a peer mentor for Marshawn and encouraged his achievement through role modeling, advice giving, and public affirmation of his capabilities. Similarly, five of the six participants from the University of Michigan were members of H.E.A.D.S., an organization for African American male intellectuals on campus. They all described how supported they felt by fellow H.E.A.D.S. members and how African American men in the organization introduced each other to various institutional resources for academic support and leadership opportunities.

The high-achievers' interactions with and support for each other sometimes extended beyond their campuses. For instance, Ohio State student Cullen Buie and Purdue student Landon Lockhart were close friends in high school and continued to encourage each other throughout the college years. Three participants from three dif- 
ferent campuses met during an eight-week summer internship program at Procter \& Gamble in Cincinnati and remained connected for support upon returning to their respective universities. Also, Marshawn, Landon, Arnold, and Ted, all members of Alpha Phi Alpha, knew each other from district fraternity meetings and leadership conferences. A senior at Michigan State acknowledged another participant at the University of Illinois whom he had met at a leadership retreat his sophomore year; reportedly, the two regularly kept in touch and exchanged advice on winning campus elections. Clarence attended a national conference for African American student leaders in Virginia the previous year. "I thank God for that trip. It was so refreshing to meet other Black student leaders and achievers. Keeping in touch with them has been a source of inspiration for me to continually strive toward greatness here at Michigan State," he added. Each high-achiever cited African American peers on his campus and beyond who supported, encouraged, and uplifted him.

\section{Leveraging Peer Support}

The Bible says that if you let your light shine, people will recognize you. I'm a Christian, and I try to live my life for the Lord by treating people like I want to be treated. My peers support me because they know my efforts to advance the African American community here at Michigan State are genuine; it's not an act and I'm not a fake.

Robert's reflections are characteristic of the many explanations given by the 32 high-achievers articulating the volume of support extended by same-race peers. Each participant perceived himself as personable, indicating that he led by example and served as a role model for others. These personal characteristics garnered peer support for the African American men in this study. They also thought their peers deemed them credible because they had demonstrated excellence in prior leadership roles on their campuses. "I am known to get the job done and give it my all," DeJuan contended. "That's why people respect and support me." Regarding their reputations as student leaders, Clarence said he was known to "put up or shut up," while Amondo indicated that he was a trustworthy innovator who effectively conveyed the needs of African American students to administrators at his university.

As previously mentioned, the participants were primarily involved in predominantly Black student organizations on their campuses. Their demonstrated dedication to Black and minority causes was one way same-race peer support was earned. Michael asked, "How can I be a sellout when the bulk of my waking energy is devoted to Black activities and clubs? No one has ever accused me of such because my contributions and my Blackness speak for themselves." In addition to serving as advocates for African American student interests, the participants also discussed their outreach efforts to other African American men. A participant at Ohio State commented:

I have earned the respect of several brothas' on this campus because I am the one who is always pulling on their coattails saying, "Come on, get involved in this Black club, or come out to this 
Black event." Even though they don't always accept the invitation, they know how committed I am to uplifting our race.

Regarding leadership in Black student organizations, Michael added that "someone's gotta do it. They support me because I am one of the few African American males who helps get it done."

Raymond similarly also elaborated on the nexus between his leadership and the support he received from other African American students, especially men, at the University of Michigan.

Brothas' understand that I am not just doing it for myself, but for other brothas' and sistas.' Because of that, I have a lot of respect from everyone on campus . . . even the Black male student-athletes know what I am doing, and they respect me so much.

Because they were visible spokespeople for the African American communities on their campuses, the high-achievers thought their peers saw them as leaders with whom they could identify. "Because I am one of their main ambassadors here at Purdue, Black students are proud of me when I excel, and they can identify with me as a charismatic Black male leader," David claimed. Clarence offered similar remarks: "I treat other African Americans as if they are my sisters and brothers, more than just acquaintances and constituents. Most of them know me, and they identify with me, even though they may make different choices." In sum, their demonstration of character and their reputations for being role models, reliable student leaders, and champions of African American student issues are the ways in which the 32 high-achievers were able to garner same-race peer support for their leadership and college achievements.

\section{Discussion and Implications}

Kunjufu (1988) posits that African American boys in primary and secondary schools are forced by their peers to choose between being popular and being smart. The participants in this study have successfully negotiated being both. Fordham and Ogbu (1986) claim these social pressures are often rooted in the belief that school achievement is characteristic of White students, not African Americans. As such, high-achieving African American students are often accused of "acting White." The participants in the present study reported dissimilar interactions with their same-race peers. Instead of accusing them of "acting White," other African Americans on the six campuses (including uninvolved male students) encouraged the high-achievers, supported their leadership, and applauded their successes. In fact, the participants unanimously cited support from their African American peers as essential to their success in college. Thus, the results of this study do not support Fordham and Ogbu's "acting White" hypothesis. Instead, findings here confirm previous assertions that African American students value their own and their peers' educational achievement. Furthermore, many high-achievers have positive self-esteem, high goal orientations, and strong Black identities (Ainsworth-Darnell \& Downey, 1998; 
Cook \& Ludwig, 1998; Ferguson, 2001; Spencer, Noll, Stolzfus, \& Harpalani, 2001).

It appears that the high-achiever's active involvement in initiatives to advance the African American community on his campus and to ensure that Black concerns were heard by the administration helped protect him from any possible peer perceptions of White-likeness. To "act White" yet hold major leadership positions in predominantly Black student organizations is illogical. Likewise, "acting White" suggests a weak racial identity and a lack of familiarity with issues affecting the African American community. Reportedly, other African American students on the six campuses were well aware of the high-achievers' efforts to address Black issues through involvement in organizations and participation on major campus committees. The breadth of the participants' achievements as well as their visibility on campus seemed to have shaped their peers' perceptions. If they were solely academic achievers instead of well-rounded student leaders who achieved both inside and outside the classroom, perhaps their peers would have rendered a different verdict on their Blackness. This conjecture deserves empirical exploration.

High-achieving students in Fries-Britt's (1995) study relied heavily on a racespecific program for academically talented students to meet and interact with other African Americans. Although many of the high-achievers in the present study participated in special academic success programs for racial/ethnic minority students (e.g., the Minority Achievers Program at Indiana University), serving as members of Black fraternities and leaders of other Black student organizations were the primary ways through which they were afforded opportunities to interact with other African Americans. Fries-Britt (1997) maintains, "Establishing peer group connections for gifted Black students can be difficult as they seek to find other students who share their interest and level of ambition" (p. 3). Again, engagement in student organizations provided the high-achievers a chance to interact with African American students who were committed to similar causes and had common interests. Beyond serving as venues for meeting other highly involved students, leadership in Black student organizations also enabled the participants to establish connections with uninvolved African American students whose social needs were met and voices were represented through those organizations.

Several researchers have found that high-achieving African American students in K-12 schools "camouflage" their academic talent in order to fit in with their samerace peers (Ford, 1996; Fordham \& Ogbu, 1986; Grantham \& Ford, 2003; Horvat \& Lewis, 2003). Clearly, that was not the case in the present study. Because the participants were viewed as role models by other African American students on campus, they were expected to do well in their classes and to continually represent excellence in their out-of-class endeavors. Therefore, they did not hide their talents or keep secret their accomplishments. It appears that the more their same-race peers became familiar with their contributions and achievements, the more they supported the highachievers. Furthermore, the participants in the present study did not embrace "racelessness" as Fordham (1988) suggested, nor did they assimilate into White culture as Fries-Britt and Turner (2002) say many high-achieving African American students do. Instead, they were engaged in an array of activities on their campuses and devoted a significant portion of their energies and efforts to Black causes. 
Contextual differences also seem to account for differences in same-sex peer reactions to engagement in activities other than those that characterize what Harper, Harris, and Mmeje (2005) call "context-bound gendered social norms"-prescriptive and locally agreed-upon masculine attitudes and behaviors. Like the participants in Davis's (2003) study, African American men on the six university campuses had developed masculine codes of conduct that were primarily characterized by athleticism and physical activity, the pursuit of romantic relationships with female students, being perceived as "cool," and various attitudinal and behavioral norms that did not focus on academic achievement. However, participants in the present study indicated that there were opportunities for negotiation, which is different from Davis's findings. Davis (2001) reported that those who fail to adhere to the masculine code are victimized by their peers and expelled from boy networks at school. Although the decisions they made regarding the expenditure of their out-of-class time were far from normative, the high-achievers felt extremely supported by their same-race male peers. This shift in African American male peer support for activities beyond "the masculine code" from middle school to college should be explored more deeply.

Four practical implications for college and university administrators can be derived from this study. First, support (financial and otherwise) for predominantly Black clubs and minority student groups is imperative, as those organizations serve as the primary venues through which Black leadership is developed and achievement is embraced. Second, given the role of the five historically Black fraternities in offering social support and academic encouragement to African American male undergraduates, attempts should be made to sustain these organizations and increase African American male interest in membership. Third, because they afford opportunities for the cultivation of meaningful relationships with others who share similar values, goals, and experiences, administrators should commit financial resources for African American students to attend conferences and participate in leadership retreats. This is especially important because student leaders may find peer connections, validation, and support in these external venues that may not be available locally. Last, programming (e.g., a conversation series) that brings together members of different African American student subgroups to discuss the importance of peer support and confront internalized racism is necessary.

In light of the findings that emerged in this study, two lingering questions are worthy of acknowledgment: (1) Is immunity from internalized racism and accusations of "acting White" extended to those who are not interested in becoming student leaders or being actively involved in predominantly Black student organizations, and (2) given the apparent strength of the participants' Black identities, would African American achievers whose racial identities are not as well-developed or as widely publicized also receive support from their same-race peers for their college achievements? While leadership and active engagement served as negotiation tools for the high-achievers, there is insufficient evidence to suggest that they would have been treated differently were they not as involved. In fact, the participants indicated that basic character traits (being dependable, approachable, fair, hard-working, etc.) also garnered same-race peer support. As noted previously, few researchers have explored the "acting White" hypothesis and internalized racism 
within the context of higher education. Additional effort should be devoted to investigating these concepts among various subgroups of African American collegians: uninvolved high academic achievers versus academically successful student leaders, those with strong Black identities versus students who embrace "racelessness," and African American women versus their same-race male counterparts.

\section{Conclusion}

There was no evidence of internalized racism - at least in the domains of academic achievement and Black male leadership — on the six campuses where data were collected for this study. Though different from the majority of their same-race male peers, the participants' achievements were not deemed abnormal or characteristically White. While there may possibly be limited encouragement for actually attending college (which was not explored in this study), it is clear that support and validation exist on university campuses once African American men enroll. For those who wish to make the most of their experiences both inside and outside the classroom, same-race peer support and opportunities for meaningful engagement with other African American students are both possible and likely. After listening to Kanye West's (2004) The College Dropout, one may erroneously conclude that college attendance, let alone college achievement, is extremely unpopular among African Americans. The experiences of the 32 African American men in this study confirm otherwise.

\section{References}

Ainsworth-Darnell, J. W., \& Downey, D. B. (1998). Assessing the oppositional culture explanation for racial/ethnic differences in school performance. American Sociological Review, 63(4), 536-553.

Astin, A. W. (1993). What matters in college? Four critical years revisited. San Francisco: Jossey-Bass.

Baldwin, A. Y. (1991). Gifted Black adolescents: Beyond racism to pride. In M. Bireley \& J. Genshaft (Eds.), Understanding the gifted adolescent: Educational, developmental and multicultural issues (pp. 231-239). New York: Teachers College Press.

Baker, D. G. (1983). Race, ethnicity and power: A comparative study. Boston: Routledge.

Bonner II, F. A. (2001). Gifted African American male college students: A phenomenological study. Storrs, CT: The National Research Center on the Gifted and Talented.

Carnegie Foundation for the Advancement of Teaching. (2000). The Carnegie classification of institutions of higher education. Stanford, CA: Author.

Cook, P. J., \& Ludwig, J. (1998). The burden of "acting White": Do Black adolescents disparage academic achievement? In C. Jencks \& M. Phillips (Eds.), The BlackWhite test score gap (pp. 375-400). Washington, DC: Brookings Institution Press.

Cooley, M. R., Cornell, D. G., \& Lee, C. (1991). Peer acceptance and self-concept of Black students in a summer gifted program. Journal for Education of the Gifted, 14, 166-177. 
Davis, J. E. (1994). College in black and white: Campus environment and academic achievement of African American males. Journal of Negro Education, 63(4), 620-633.

Davis, J. E. (1999). What does gender have to do with the experiences of African American college men? In V. C. Polite \& J. E. Davis (Eds.), African American males in school and society: Practices and policies for effective education (pp. 134-148). New York: Teachers College Press.

Davis, J. E. (2001). Black boys at school: Negotiating masculinities and race. In R. Majors (Ed.), Educating our Black children: New directions and radical approaches (pp. 169-182). New York: RoutledgeFalmer.

Davis, J. E. (2003). Early schooling and academic achievement of African American males. Urban Education, 38(5), 515-533.

Denzin, N., \& Lincoln, Y. (2000). Introduction: The discipline and practice of qualitative research. In N. Denzin \& Y. Lincoln (Eds.), Handbook of qualitative research (2nd ed., pp. 1-28). Thousand Oaks, CA: Sage.

Essed, P. (1991). Understanding everyday racism. London: Sage.

Ferguson, R. F. (2001). A diagnostic analysis of Black-White GPA disparities in Shaker Heights, Ohio. Brookings Papers on Education Policy, 2001, 347-414.

Ford, D. Y. (1996). Reversing underachievement among gifted Black students: Promising practices and programs. New York: Teachers College Press.

Ford, D. Y., \& Harris III, J. J. (1995). Underachievement among gifted African American students: Implications for school counselors. School Counselor, 42(3), 196-203.

Ford, D. Y., \& Harris III, J. J. (1997). A study of the racial identity and achievement of Black males and females. Roeper Review, 20(2), 105-110.

Fordham, S. (1988). Racelessness as a strategy in Black students' school success: Pragmatic strategy or pyrrhic victory? Harvard Educational Review, 58(1), 54-84.

Fordham, S., \& Ogbu, J. U. (1986). Black students' school success: Coping with the "burden of 'acting White." Urban Review, 18(3), 176-206.

Freire, P. (1970). Pedagogy of the oppressed. New York: Continuum.

Fries-Britt, S. L. (1997). Identifying and supporting gifted African American men. In M. J. Cuyjet (Ed.), Helping African American men succeed in college. New directions for student services (No. 80, pp. 65-78). San Francisco: Jossey-Bass.

Fries-Britt, S. L. (1998). Moving beyond Black achiever isolation: Experiences of gifted Black collegians. Journal of Higher Education, 69(5), 556-576.

Fries-Britt, S. L. (2002). High-achieving Black collegians. About Campus, 7(3), 2-8.

Fries-Britt, S. L. (2004). The challenges and needs of high-achieving Black college students. In M. C. Brown II \& K. Freeman (Eds.), Black colleges: New perspectives on policy and practice (pp. 161-176). Westport, CT: Praeger.

Fries-Britt, S. L., \& Turner, B. (2001). Facing stereotypes: A case study of Black students on a White campus. Journal of College Student Development, 42(5), 420-429.

Fries-Britt, S. L., \& Turner, B. (2002). Uneven stories: Successful Black collegians at a Black and a White campus. The Review of Higher Education, 25(3), 315-330.

Gay, G. (2000). Culturally responsive teaching. New York: Teachers College Press. 
Grantham, T. C., \& Ford, D. Y. (2003). Beyond self-concept and self-esteem: Racial identity and gifted African American students. The High School Journal, 87(1), 18-29.

Griffin, K. (2006). Striving for success: A qualitative exploration of competing theories of high-achieving Black college students' academic motivation. Journal of College Student Development, 47(4), 384-400.

Harper, S. R. (2004). The measure of a man: Conceptualizations of masculinity among high-achieving African American male college students. Berkeley Journal of Sociology, 48(1), 89-107.

Harper, S. R. (2005a). Leading the way: Inside the experiences of high-achieving African American male students. About Campus, 10(1), 8-15.

Harper, S. R. (2005b, November). High-achieving African American men's behavioral responses to stereotypes at predominantly White universities. Paper presented at the annual meeting of the Association for the Study of Higher Education, Philadelphia, PA.

Harper, S. R. (2006a). Black male students at public flagship universities in the U.S.: Status, trends, and implications for policy and practice. Washington, DC: Joint Center for Political and Economic Studies.

Harper, S. R. (2006b). Enhancing African American male student outcomes through leadership and active involvement. In M. J. Cuyjet (Ed.), African American men in college (pp. pp. 68-94). San Francisco: Jossey-Bass.

Harper, S. R., Harris III, F., \& Mmeje, K. C. (2005). A theoretical model to explain the overrepresentation of college men among campus judicial offenders: Implications for campus administrators. NASPA Journal, 42(4), 565-588.

Hill Collins, P. (2004). Black sexual politics: African Americans, gender, and the new racism. New York: Routledge.

Hollins, E. R., \& Spencer K. (1990). Restructuring schools for cultural inclusion: Changing the schooling process for African American youngsters. Journal of Education, 172, 89-100.

Holstein, J. A., \& Gubrium, J. F (1995). The active interview. Qualitative research method series (No. 37). Thousand Oaks, CA: Sage.

hooks, b. (2004). We real cool: Black men and masculinity. New York: Routledge.

Horvat, E. M., \& Lewis, K. S. (2003). Reassessing the "burden of 'acting White"": The importance of peer groups in managing academic success. Sociology of Education, 76(4), 265-280.

Irvine, J. J. (1990). Black students and school failure. Westport, CT: Greenwood Press.

Jones, C. P. (2000). Levels of racism: A theoretical framework and a gardener's tale. American Journal of Public Health, 90(8), 1212-1215.

Kunjufu, J. (1988). To be popular or smart: The Black peer group. Chicago: African American Images.

Ladson-Billings, G. J. (1995). Toward a theory of culturally relevant pedagogy. American Education Research Journal, 35, 465-491.

Lindstrom, R. R., \& Van Sant, S. (1986). Special issues in working with gifted minority adolescents. Journal of Counseling and Development, 64, 583-586. 
Lipsky, S. (1987). Internalized racism. Seattle: Rational Island Publishers.

Miles, M. B., \& Huberman, A. M. (1994). Qualitative data analysis: An expanded sourcebook (2nd ed.). Thousand Oaks, CA: Sage.

Moustakas, C. (1994). Phenomenological research methods. Thousand Oaks, CA: Sage.

National Center for Education Statistics. (2005). Integrated postsecondary education data system. Washington, DC: U.S. Department of Education, Institute of Education Sciences.

Ogbu, J. U. (2004). Collective identity and the burden of "acting White" in Black history, community, and education. The Urban Review, 36(1), 1-35.

Ogbu, J. U., \& Simons, H. D. (1998). Voluntary and involuntary minorities: A cultural-ecological theory of school performance with some implications for education. Anthropology and Education Quarterly, 29(2), 155-188.

Pheterson, G. (1990). Alliances between women: Overcoming internalized oppression and internalized domination. In L. Albrecht \& R. Brewer (Eds.), Bridges of power: Women's multicultural alliances (pp. 34-48). Philadelphia, PA: New Society.

Polkinghorne, D. E. (1989). Phenomenological research methods. In R. S. Valle \& S. Halling (Eds.), Existential-phenomenological perspectives in psychology (pp. 4160). New York: Plenum.

Pyke, K., \& Dang, T. (2003). "FOB" and "Whitewashed": Identity and internalized racism among second generation Asian Americans. Qualitative Sociology, 26(2), 147-172.

Spencer, M. B., Noll, E., Stolzfus, J., \& Harpalani, V. (2001). Identity and school adjustment: Revisiting the "acting White" assumption. Educational Psychologist, 36(1), 21-30.

West, K. (2004). The college dropout [CD]. New York: Roc-a-Fella Records. 
Copyright of Journal of Men's Studies is the property of Men's Studies Press and its content may not be copied or emailed to multiple sites or posted to a listserv without the copyright holder's express written permission. However, users may print, download, or email articles for individual use. 